\title{
Proof of Concept for Shoot Blight and Fire Blight Canker Management with Postinfection Spray Applications of Prohexadione-Calcium and Acibenzolar-S-Methyl in Apple
}

\author{
Srdan G. Aćimović, ${ }^{1, \dagger}$ Christopher L. Meredith, ${ }^{2}$ Ricardo Delgado Santander, ${ }^{2}$ and Fatemeh Khodadadi ${ }^{2}$ \\ ${ }^{1}$ Department of Plant Pathology, Physiology, and Weed Science, School of Plant and Environmental Sciences, Alson H. Smith Jr. \\ Agricultural Research and Extension Center, Virginia Polytechnic Institute and State University, Winchester, VA 22602 \\ ${ }^{2}$ Plant Pathology and Plant-Microbe Biology Section, School of Integrative Plant Sciences, Hudson Valley Research Laboratory, \\ Cornell University, Highland, NY 12528
}

\begin{abstract}
To reduce the severity of shoot blight and prevent the resulting development of cankers on perennial apple wood, we evaluated eight fire blight postinfection spry programs of prohexadione-calcium (PCA) alone or with acibenzolar-S-methyl (ASM) over 2 years. On mature trees of cultivar Royal Court, a single application of the high PCA rate $(247 \mathrm{mg} / \mathrm{liter})$ at 2 to 3 days after inoculation resulted in 89.5 and $69.5 \%$ reduction of shoot blight severity after inoculation. Two applications of PCA $247 \mathrm{mg} / \mathrm{liter} 12$ or 14 days apart, with the first one applied 2 to 3 days after inoculation, resulted in 78.8 and $74.5 \%$ reduction of shoot blight severity in both years. A $100 \%$ control of

with lower PCA rates and frequencies of application reduced shoot blight severity 50.8 and $51.8 \%$ (PCA) and 62.6 to $72 \%$ and $59.3 \%$ $(\mathrm{PCA}+\mathrm{ASM})$ over 2 years, respectively. Reduction of canker incidence on wood by the other programs was $66.5 \%$ and 69 to $90.4 \%$ in the two years, respectively. As fire blight cankers lead to death of dwarf apple trees and serve as primary sources of inoculum, our effective PCA and PCA + ASM programs could serve as viable postinfection management options. These treatments can reduce or prevent canker development and thus significantly abate tree losses in high-density apple orchards after fire blight epidemics occur.
\end{abstract} canker incidence on perennial wood from infected shoots in both years was achieved with a single application of PCA $(247 \mathrm{mg} / \mathrm{liter})$ applied at 2 or 3 days after the inoculation, and three applications of PCA ( $125 \mathrm{mg} / \mathrm{liter})+$ ASM ( $25 \mathrm{mg} / \mathrm{liter}) 12$ to 16 days apart reduced canker incidence by 83.5 and $69 \%$ in the 2 years. The other programs

Keywords: acibenzolar-S-methyl, Erwinia amylovora, fire blight, post-infection control, prohexadione-calcium, rescue treatment, shoot blight

The fire blight bacterium Erwinia amylovora (Burrill 1882) (Winslow et al. 1920), which causes the disease fire blight of apple, survives primarily in the wood bark around the canker edges and below the cankers developed from flower and shoot infections (Santander et al. 2019). With warm and humid conditions in spring, the pathogen emerges in the form of bacterial ooze on the edge of some fire blight cankers. Carried by insect vectors, rain, or wind, it reaches stigma of open flowers or the surface of young shoots (Van Der Zwet and Keil 1979). Infections occur by cells entering nectarthodes after being washed into the flowers or through leaf hydathodes and/or wounds on shoots caused by wind, hail, or insects (Van der Zwet et al. 2012; Zeng et al. 2020). After causing blossom and shoot blight, E. amylovora invades tree wood tissues from

†Corresponding author: S. G. Aćimović; acimovic@vt.edu

Funding: This work was supported by New York State Farm Viability Institute competitive grants program 2017, grant 81927/A001-FVI 17-006 (to S.G.A.) for the project "Development of effective spray program for post-infection fire blight management in apples and cost-benefit analysis of its key components" and in part by New York State Department of Agriculture and Markets Apple Research and Development Program 2018-2019 grant NYS ESDC ARDP 86698-11419 (to S.G.A.) for the project "Continued lab detection of fire blight bacterium Erwinia amylovora in susceptible apple rootstocks in NY orchards and Hudson Valley research laboratory efficacy trials."

*The $e$-Xtra logo stands for "electronic extra" and indicates there are supplementary materials published online.

The author(s) declare no conflict of interest.

Accepted for publication 3 July 2021.

@ 2021 The American Phytopathological Society infected succulent organs and develops new fire blight cankers, repeating the cycle (Aćimović et al. 2014, 2019).

E. amylovora holds a significant potential to decimate apple production worldwide. In years with conducive weather conditions, it may lead to significant tree death, especially on susceptible cultivars/ rootstocks. In 1991 and 2000 in Michigan and in 1998 in Washington and Oregon, fire blight resulted in $\$ 3.8, \$ 42$, and $\$ 68$ million total economic losses, respectively, with removal of as much as 450,000 trees in Michigan (Douglas 2006; Longstroth 2001). In the state of New York, U.S.A. (henceforth "NY"), major fire blight outbreaks were reported in the counties along Lake Ontario during 2000 (Douglas 2006), and sudden and unexpected fire blight outbreaks caused 50\% apple tree losses in young, recently planted orchards (Breth 2008). In 2016, a fire blight outbreak in northern NY led to $>\$ 16$ million in damage (Aćimović and Meredith 2017). The most affected were high- and medium-density apple orchards with spindle-shaped tree training systems on dwarfing rootstocks $(1,200$ to 5,000 trees/ha). An average of 2,500 trees per farm were removed because of fatal fire blight cankers on scaffolds, trunks, and rootstocks. Removal of trees continued in 2017 as a result of latent fire blight infections. In older orchards with classic training systems, 20 to $40 \%$ of bud wood was lost as a result of the removal of infected wood (Aćimović and Meredith 2017).

Because of global climate change, climate patterns in the Northeastern United States have become warmer and wetter, with a $0.09^{\circ} \mathrm{C}$ and $10-\mathrm{mm}$ increase in temperature and precipitation per decade, respectively, and a $70 \%$ increase in the amount of precipitation falling in heavy rain events (Groisman et al. 2013; Kunkel et al. 2013). Although new high temperature records are increasing nationally, the largest increases are reported in the midwestern and northeastern United States (Frumhoff et al. 2007; Hayhoe et al. 2007). With the warmer and wetter weather patterns in spring (Ault et al. 2015; Keenan et al. 2014; Menzel et al. 2006;), we predict that more fire blight epidemics are poised to occur in the temperate apple-growing regions of the United States (CBC News 2014, 2016; 
Pautasso et al. 2012). In NY, infection events that lead to fire blight epidemics usually occur from mid- to late May, which usually coincides with early to late petal fall as well as the time when apple shoots initiate growth (Aćimović and Meredith 2017).

One of the factors that contributed to the 2016 epidemic in NY is the adoption of high-density plantings (1,200 to 5,000 trees/ha). In such orchards, trees are grown in narrow columnar-shaped training systems (e.g., tall spindle, super spindle, vertical axis, Y-trellis). Compact tree stands favor rapid E. amylovora spread, both on and in the trees, because (i) fruiting limbs of adjacent trees are very close to each other, comprising a tree hedge and allowing flower clusters to overlap, thus facilitating easier tree-to-tree dissemination of inoculum; (ii) the established flower or shoot blight infections can quickly progress from branches into the trunk because the fruiting limbs are shorter, thinner, and younger in comparison to the older, longer, and thicker limbs of the classic training systems (e.g., freestanding central leader); and, (iii) during annual dormant pruning each winter, one to four limbs on the tree trunk that are thicker than $20 \mathrm{~mm}$ at the base are removed to encourage shoot renewal for future branches, leading to new shoot growth, which is extremely susceptible to fire blight. In infected shoots, the pathogen may travel systemically within the shoot to woody tissue, producing cankers on limbs and trunk. Cankers act as the overwintering site for the pathogen (Slack and Sundin 2017), producing inoculum for infections in future seasons, and may increase the chance for treetop die-off by girdling and/or tree death.

Fire blight outbreaks in NY frequently express for the first time as shoot blight in late June to July, increasing the significance of this stage for disease management (Aćimović and Meredith 2017; Wallis and Cox 2020). Infected shoots are possible locations for canker initiation on wood, which then serve as the prime sites for survival of $E$. amylovora in winter (Slack and Sundin 2017; Sundin 2014). Fire blight cankers on thicker branches and trunk have the greatest chance to harbor viable inoculum for flower or shoot infections in spring (Van Der Zwet and Keil 1979; Vanneste and Eden-Green 2000). As few as one to four cankers per hectare might be sufficient to allow fire blight infection renewal in the next growing season (Brooks 1926; Tullis 1929). In spring, E. amylovora emerges on the surface of overwintered cankers as droplets of bacterial ooze (Schroth et al. 1974; Vanneste and Eden-Green 2000). Pruning removal of cankers can reduce or eradicate primary bacterial inoculum (Slack and Sundin 2017). However, as many as seven cankers per hectare can remain undetected after winter pruning on perennial apple wood (Aćimović et al. 2014).

In recent years, there is an increasing need for alternative spray application options that are effective, do not promote development of antibiotic resistance in E. amylovora, and can be used until research in functional bacterial genomics and host-pathogen interactions translates new pathogen management knowledge into commercial production (Sundin et al. 2016). Fire blight is controlled during apple bloom and petal fall typically by spray application(s) of the antibiotic streptomycin or, in some locations, kasugamycin (McGhee and Sundin 2011) before or $24 \mathrm{~h}$ after the infection events determined by fire blight models in Network for Environment and Weather Applications like Maryblyt7.1.1 (Steiner 1988, 1990; Turechek and Biggs 2015), CougarBlight (Smith 2000; Smith and Pusey 2011), and RIMproErwinia (Philion and Trapman 2011), which are available online (http:// newa.cornell.edu/index.php?page=apple-diseases; http://grapepathology. org/maryblyt; https://rimpro.eu). There is a narrow window within 48 $\mathrm{h}$ before or $24 \mathrm{~h}$ after the predicted infection for growers to accomplish adequate control. Hence, one of the aims of this paper was to addresses the critical question of which active ingredients a grower can apply if that window has been missed.

There are no inoculation studies in mature apple trees that evaluate the efficacy of various rates and application timings of plant growth regulators (PGRs) and/or systemic acquired resistance (SAR) activators in reduction of fire blight cankers. Prohexadione-calcium (PCA) is a valuable PGR that activates structural resistance in vegetative apple tissues to E. amylovora (Sundin 2014) (Apogee, BASF Corporation; Kudos 27.5 WDG; Fine Americas). PCA inhibits gibberellin biosynthesis, which reduces longitudinal apple shoot growth and increases the thickness of cell walls in cortical parenchyma, thus preventing invasion of shoot tissues by E. amylovora and reducing shoot susceptibility to fire blight (Evans et al. 1999; McGrath et al. 2009; Ramirez et al. 2005; Wallis and Cox 2020). Preventive spray applications of PCA are recommended in commercial apple orchards starting at the 2.5- to $5-\mathrm{cm}$ shoot growth stage and continuing at 1- to 4-week intervals after the first application because they reduce shoot blight incidence as much as $83 \%$ and shoot blight severity as much as $86 \%$ (Momol et al. 1998; Yoder et al. 1999). In addition to its use for fire blight, PCA is often used to control fruit tree vigor and size, especially on vigorous rootstocks, and can mitigate a currently established fire blight outbreak and prevent the shoot infections from renewing in the growing season following an outbreak. Recently, PCA applied at pink bud stage was shown to thicken the cell walls in the cortical parenchyma of apple flower and fruitlet pedicels and prevent their invasion by E. amylovora, leading to 71 and $77 \%$ control of blossom and shoot blight, respectively (Wallis and Cox 2020). Because of its indirect mode of action impacting the plant host, resistance development in E. amylovora to PCA is unlikely (Spinelli et al. 2005).

The SAR activator acibenzolar-S-methyl (ASM) upregulates pathogenesis-related protein genes in apple leaves linking SAR, which is a "whole-plant" resistance response, with a specific defense signaling pathway (Aćimović et al. 2015; Maxson-Stein et al. 2002). ASM can reduce shoot blight severity and trunk canker size on trunks and rootstocks of immature apple trees after inoculation with E. amylovora (Johnson and Temple 2016; Johnson et al. 2016; MaxsonStein et al. 2002). However, use of ASM is largely thwarted by the high price of the marketed formulation (Environmental Protection Agency registration no. 100-922) and because it only suppresses fire blight when applied by spraying (Thompson et al. 2021).

Preventive spray applications of PCA under natural infection conditions reduced shoot blight incidence and severity and the resulting fire blight cankers by 61 to $96 \%$ on perennial apple wood (Norelli and Miller 2004; Yoder 2001; Yoder and Marini 2002; Yoder et al. 1999). However, PCA use is still largely limited to preventive spray applications on shoots in the spring following a year with a severe fire blight outbreak. The main concern for PCA use is growth reduction on 1- to 5-year-old trees when filling the row space with tree canopy and reaching the top trellis wire are priorities in high-density orchards. The same concern limits PCA use in mature apple orchards except in some regions like New Zealand, where PCA is frequently used to regulate tree vigor because of nutrient-rich soils and widespread use of semidwarfing rootstock G.202, which is replacing M.26 (eXtension 2019; Norelli et al. 2003; Regalis Xtra 2019). In young and high-density orchards, fire blight infections cannot be tolerated because of the greater susceptibly of juvenile host tissues (Johnson et al. 2016) and the smaller tree sizes in comparison with the classical orchards. We believe that PCA application(s) after a severe fire blight infection, which was not controlled by timely antibiotic applications, holds potential in high-density orchards to prevent or significantly reduce tree death resulting from $E$. amylovora invasion of the wood and initiation of cankers.

We postulate that PCA applied before symptom development on already infected shoots could reduce shoot blight severity. However, it is not known how many applications of PCA, at which application rate, and at what time delivered postinfection it can prevent or reduce the invasion of shoots and wood by E. amylovora. PCA applied this way could curtail the initiation of destructive fire blight cankers on perennial wood that can kill mature and young dwarf trees. Several studies show that the SAR activator ASM can reduce shoot blight severity (42\%) and the size of cankers on trunks (48\%) and rootstocks (92\%) of immature apple trees after inoculation with E. amylovora (Johnson and Temple 2016; Johnson et al. 2016; Maxson-Stein et al. 2002). However, the combined effect of PCA and ASM has not been investigated for reduction of shoot blight and canker formation.

The objective of this study was to determine the effect of different rates and numbers of postinoculation spray applications of PCA over time, alone or in combination with nonionic surfactant and/or ASM, on shoot blight severity and development of the resulting fire blight cankers. We hypothesized that, in addition to the expected 
shoot blight severity reduction, the highest PCA rates, the most frequent applications, and the combination of PCA with a surfactant and/or ASM applied postinoculation would reduce or prevent initiation of fire blight cankers on mature trees. Inclusion of a surfactant would improve uptake of PCA into the shoots and accelerate defensive effects of the host; ASM's effect on host immunity would offer increased defenses in combination with PCA. Our goal was to demonstrate the concept of an effective postinfection spray program(s) using PCA to reduce or prevent initiation of fire blight cankers on wood. If efficacious, these treatments could reduce tree deaths in high-density apple orchards. Such PCA programs would be applied shortly after the fire blight prediction model(s) reported a recent infection event (based on historical weather data) that has not been managed in a timely manner with preventive application of antibiotic agent $(\leq 24 \mathrm{~h}$ after infection established on opened flowers).

\section{Materials and Methods}

Bacterial strain and inoculum preparation. Experiments were carried out with the E. amylovora strain Ea273 grown overnight in a shaker incubator in Luria-Bertani broth (Bertani 1951) at $28^{\circ} \mathrm{C}$. Inocula were prepared in $10 \mathrm{mM}$ phosphate buffered saline (PBS) solution, $\mathrm{pH} 7.4$, adjusting cell suspensions to approximately $2 \times 10^{8}$ CFU using a DEN-1 McFarland Densitometer (Grant Instruments) and McFarland Standard calibration set 0.5-4.0 (Pro-Lab Diagnostics). Colony plate counts in 2018 determined that suspension concentrations were $7 \times 10^{8} \mathrm{CFU} / \mathrm{ml}$ on 15 May and $3 \times 10^{9} \mathrm{CFU} / \mathrm{ml}$ on 14 June, which is within the preferred range(s) for shoot blight control evaluations and fire blight canker initiation on wood (Aćimović et al. 2014; Johnson and Temple 2016). In 2019, colony plate counts determined that the suspension concentration used on 18 May was $2.3 \times 10^{8} \mathrm{CFU} / \mathrm{ml}$.

Plant material and shoot inoculations. Apple orchard experiments evaluating postinfection fire blight management programs were performed at Cornell University's Hudson Valley Research Laboratory in Highland, NY, U.S.A. $\left(41^{\circ} 44^{\prime} 59.6^{\prime \prime} \mathrm{N}, 73^{\circ} 58^{\prime} 3.4^{\prime \prime} \mathrm{W}\right)$, in a block of Malus $\times$ domestica cultivar Royal Court trees on M.9(337)/ EMLA111 interstem, planted in 2001 with 9 m between trees and 7.6 $\mathrm{m}$ between rows. Soil fertilization schedule was as follows: 9 May $2018,79.4 \mathrm{~kg}$ of nitrogen, phosphorus, and potassium (NPK) 15-0-30 with B, delivering $46 \mathrm{~kg}$ N/ha; 16 April 2019, $72.6 \mathrm{~kg}$ of NPK 25-3-9, delivering $69.5 \mathrm{~kg} \mathrm{~N} / \mathrm{ha}$.

Two inoculations in 2018 (15 May, 14 June) and one in 2019 (18 May) were performed. Two inoculations in 2018 were used to increase infection pressure because this is reflective of natural conditions in commercial orchards. Briefly, 2.5- to 7.5-cm-long shoots (petal fall 2018 and 2019) and 15- to 45-cm-long shoots (1 month after petal fall 2018) were inoculated with sterile scissors dipped in an E. amylovora cell suspension in $10 \mathrm{mM}$ PBS solution by cutting the second or third youngest unfolded leaf on the succulent shoot tip as described previously (Koczan et al. 2009; McGhee and Sundin 2011). The inoculum in PBS solution was cooled on ice until inoculation. A total of 10 shoots per tree and three trees per spray program were inoculated with $E$. amylovora, and an additional 10 shoots on each tree replicate were selected as treated uninoculated shoots (Supplementary Figs. S1 and S2) and similarly wounded with sterile scissors dipped in PBS solution instead. Three tree replicates were similarly wounded with sterile scissors dipped in sterile PBS solution, serving as an uninoculated untreated control. Three tree replicates were inoculated but not treated with any spray program, serving as inoculated untreated control.

Experimental design, spray programs, and application timing. An orchard experiment was designed to simulate an emergency postinfection program(s) of PCA (Apogee; BASF), PCA plus ASM (Actigard 50 WG; Syngenta Crop Protection), and copper-containing products (Badge X2, 28.2\% metallic copper; Bordeaux Mix 0.8-0.2-100, 25\% metallic copper; Table 1). These programs would be started immediately, i.e., 1.5 to 3 days after fire blight infection(s) were reported by the prediction model(s), whereas antibiotic agent was not applied before or $\leq 24 \mathrm{~h}$ after the infection event, and were continued per the timeline in the last column of Table 1 (Steiner and Lightner 1996).

The specific protocols we evaluated (Table 1) were designed to address two questions. First, what can be applied $>24 \mathrm{~h}$ after infection, i.e., if the critical window for antibiotic application was missed (1.5 to 3 days after infection event)? Apple flowering partially overlaps with shoot growth, and, in most years, when severe fire blight epidemics are reported, conducive weather conditions occurred at late bloom through petal fall, when shoots intensively grow (mid- to late May). Shoot growth starts when King bloom flowers begin to open in a flower cluster, which means the simultaneous infections of flowers and shoots can happen (Crosse et al. 1972; van der Zwet et al. 2012). Therefore, there is a narrow window for growers to accomplish adequate control by applying antibiotic agent near the infection event(s). The second question we addressed was whether the immediate application of high rates of PCA (247.1 mg/liter) in fewer applications is more effective than the application of low rates of PCA (125 mg/liter) in combination with ASM or surfactant in more applications. We expected that ASM in combination with PCA would result in greater control than PCA alone and justified the higher number of applications at a low rate because lower rates are more appealing to growers. We designed the two spray programs

Table 1. Post-infection spray programs for fire blight management evaluated in 2018 and 2019 with prohexadione-calcium (PCA), alone or in combination with acibenzolar-S-methyl (ASM), and copper to reduce shoot blight severity and initiation of fire blight cankers on perennial wood of apple cultivar Royal Court.

\begin{tabular}{|c|c|c|c|}
\hline $\begin{array}{l}\text { Program } \\
\text { no. }\end{array}$ & Spray program & $\begin{array}{l}\text { No. of applications, active } \\
\text { ingredient concentration, rate }\end{array}$ & Growth stage(s) of application ${ }^{a}$ \\
\hline 1 & One PCA $^{\mathrm{b}}$ low pink bud & $1 \times 125 \mathrm{mg} / \mathrm{liter}$ & Pink bud \\
\hline 2 & Two PCA low + surfactant $^{c}$ & $2 \times 125 \mathrm{mg} / \mathrm{liter}+250 \mathrm{ml} / 100$ liters & $2.5-$ to $7.5-\mathrm{cm}$ shoots, 12 or $14 \mathrm{DAF}$ \\
\hline 3 & One PCA high & $1 \times 247.1 \mathrm{mg} / \mathrm{liter}$ & $2.5-$ to $7.5-\mathrm{cm}$ shoots \\
\hline 4 & Two PCA high & $2 \times 247.1 \mathrm{mg} / \mathrm{liter}$ & $2.5-$ to $7.5-\mathrm{cm}$ shoots, 12 or 14 DAF \\
\hline 5 & PCA minimum $\mathrm{A}$ & $1 \times 20.6,1 \times 41.2,1 \times 20.6 \mathrm{mg} / \mathrm{liter}$ & $2.5-$ to $7.5-\mathrm{cm}$ shoots, 12 or $14 \mathrm{DAF}, 15$ or 16 DAS \\
\hline 6 & PCA minimum $\mathrm{B}$ & $1 \times 41.2,1 \times 20.6,1 \times 41.2 \mathrm{mg} /$ liter & $2.5-$ to $7.5-\mathrm{cm}$ shoots, 12 or $14 \mathrm{DAF}, 15$ or 16 DAS \\
\hline 7 & Two PCA low + ASM $^{\mathrm{d}}$ & $2 \times 125 \mathrm{mg} / \mathrm{liter}+25 \mathrm{mg} / \mathrm{liter}$ & $2.5-$ to $7.5-\mathrm{cm}$ shoots, 12 or $14 \mathrm{DAF}$ \\
\hline 8 & Two PCA low + ASM + surfactant & $2 \times 125 \mathrm{mg} /$ liter $+25 \mathrm{mg} /$ liter $+250 \mathrm{ml} / 100$ liters & $2.5-$ to $7.5-\mathrm{cm}$ shoots, 12 or 14 DAF \\
\hline 9 & Three PCA low + ASM & $3 \times 125 \mathrm{mg} / \mathrm{liter}+25 \mathrm{mg} / \mathrm{liter}$ & $2.5-$ to $7.5-\mathrm{cm}$ shoots, 12 or $14 \mathrm{DAF}, 15$ or $16 \mathrm{DAS}$ \\
\hline 10 & Three Bordeaux Mix ${ }^{\mathrm{e}} 0.8-0.2-100$ & $3 \times 224.2 \mathrm{~g} /$ ha metallic copper $+24 \mathrm{~g}$ lime $/ 100$ liters & $2.5-$ to $7.5-\mathrm{cm}$ shoots, 12 or $14 \mathrm{DAF}, 15$ or $16 \mathrm{DAS}$ \\
\hline 11 & Three Badge $X 2^{\mathrm{f}}$ & $3 \times 224.2 \mathrm{~g} / \mathrm{ha}$ metallic copper & $2.5-$ to $7.5-\mathrm{cm}$ shoots, 12 or $14 \mathrm{DAF}, 15$ or 16 DAS \\
\hline 12 & Inoculated untreated control & - & - \\
\hline 13 & Uninoculated untreated control & - & - \\
\hline
\end{tabular}

${ }^{\text {a }}$ The 2018 Application timing: pink bud, 5 May; 2.5- to 7.5-cm shoot length, 17 May; 14 DAF, 31 May; 15 DAS, 15 June. 2019 application timing: pink bud, 29 April; 2.5- to 7.5-cm shoot length, 21 May; 12 DAF, 2 June; 16 DAS, 18 June. DAF, days after first application; DAS, days after second application; ASM, acibenzolar-S-methyl; PCA, prohexadione-calcium.

b Apogee (27.5\% PCA; BASF).

${ }^{c}$ Regulaid (90.6\% 2-butoxyethanol, poloxalene, monopropylene glycol; Kalo).

d Actigard (50\% ASM; Syngenta Crop Protection).

e $99 \%$ Copper sulfate pentahydrate crystals + hydrated lime + water.

f Badge X2 (23.82\% copper oxychloride $+21.49 \%$ copper hydroxide). 
with copper (Table 1) because this bactericide, at a low rate, is used by apple growers for shoot blight management during summer and because we needed experimental mockup treatments with a different (in this case, a contact) active ingredient.

Apple tree shoots were inoculated as described above to mimic natural shoot blight infections, after which eight PCA and two copper spray programs summarized in Table 1 were evaluated for their effects on shoot blight severity, canker incidence resulting from shoot blight, and canker length compared with the uninoculated and inoculated untreated controls (Table 1). We assigned simplified spray program names (listed in the second column of Table 1) indicating the number of spray applications (one to three), PCA application rate (low for $125 \mathrm{mg} / \mathrm{liter}$, high for $247.1 \mathrm{mg} / \mathrm{liter}$, minimum for $20.6 \mathrm{mg} / \mathrm{liter}$ and $41.2 \mathrm{mg} / \mathrm{liter}$ ), and whether the program included a combination with ASM and/or surfactant. With the exception of one spray program ("one PCA low pink bud"), which was applied before shoot inoculation at a single rate of $125 \mathrm{mg} /$ liter PCA at pink bud growth stage (5 May 2018; 8 May 2019), all the other programs were initiated 2 or 3 days after inoculation, at shoot length of 2.5 to $7.5 \mathrm{~cm}$ (Table 1). Namely, spray program 2 in Table 1, designated "two PCA low + surfactant," consisted of the first spray application of $125 \mathrm{mg} /$ liter PCA $+250 \mathrm{ml} / 100$ liters of surfactant delivered 2 days (17 May 2018) or 3 days (21 May 2019) after the inoculation, at shoot length of 2.5 to $7.5 \mathrm{~cm}$, and a second application at the same rate 12 or 14 days afterward (31 May 2018; 2 June 2019). Spray program 3, designated "one PCA high," consisted of a single spray application of $247.1 \mathrm{mg} /$ liter PCA delivered 2 days (17 May 2018) or 3 days (21 May 2019) after the inoculation. Spray program 4, designated "two PCA high," consisted of the first spray application of $247.1 \mathrm{mg} / \mathrm{liter}$ PCA delivered at 2 days (17 May 2018) or 3 days (21 May 2019) after the inoculation and a second application at the same rate 12 or 14 days afterward (31 May 2018; 2 June 2019). Spray program 5, designated "PCA minimum A," consisted of the first spray application of $20.6 \mathrm{mg} /$ liter PCA delivered 2 days (17 May 2018) or 3 days (21 May 2019) after the inoculation, a second spray application of $41.2 \mathrm{mg} /$ liter PCA 12 or 14 days after the first application (31 May 2018; 2 June 2019), and a third spray application of $20.6 \mathrm{mg} / \mathrm{liter}$ PCA 15 or 16 days after the second application (15 June 2018; 18 June 2019). Spray program 6, designated "PCA minimum B," consisted of the first spray application of $41.2 \mathrm{mg} /$ liter PCA delivered 2 days (17 May 2018) or 3 days (21 May 2019) after the inoculation, a second spray application of $20.6 \mathrm{mg} / \mathrm{liter}$ PCA 12 or 14 days after the first application (31 May 2018; 2 June 2019), and a third spray application of $41.2 \mathrm{mg} /$ liter PCA 15 or 16 days after the second application (15 June 2018; 18 June 2019). Spray program 7, designated "two PCA low + ASM," consisted of the first spray application of $125 \mathrm{mg} / \mathrm{liter} \mathrm{PCA}+25 \mathrm{mg} / \mathrm{liter}$ ASM delivered at 2 days (17 May 2018) or 3 days (21 May 2019) after the inoculation and a second spray application of the same combination and rate 12 or 14 days after the first application (31 May 2018; 2 June 2019). Spray program 8, designated "two PCA low + ASM + surfactant," consisted of the same PCA and ASM rates and applications dates as program 7, except a surfactant was added to this combination at a rate of $250 \mathrm{ml} / 100$ liters. Spray program 9, designated "three PCA low + ASM," consisted of the first spray application of $125 \mathrm{mg} / \mathrm{liter}$ PCA + $25 \mathrm{mg} / \mathrm{liter}$ ASM delivered at 2 days (17 May 2018) or 3 days (21 May 2019) after the inoculation, a second spray application of $125 \mathrm{mg} / \mathrm{liter}$ PCA + $25 \mathrm{mg} /$ liter ASM delivered 12 or 14 days after the first application (31 May 2018; 2 June 2019), and a third spray application of $125 \mathrm{mg} / \mathrm{liter}$ PCA + $25 \mathrm{mg} / \mathrm{liter}$ ASM delivered 15 or 16 days after the second application (15 June 2018; 18 June 2019). Spray program 10, designated "three Bordeaux Mix 0.8-0.2-100," consisted of the first, second, and third spray applications of $224.2 \mathrm{~g} / \mathrm{ha}$ metallic copper $+24 \mathrm{~g}$ lime/100 liters on the same dates as program 9. Spray program 11, designated "three Badge X2," consisted of the first, second, and third spray applications of $224.2 \mathrm{~g} / \mathrm{ha}$ metallic copper on the same dates as programs 9 and 10 (Table 1). Spray programs were arranged in a completely randomized design in both years.

To ensure good canopy coverage, all program applications were sprayed dilute to drip (2,806 liters/ha) using a tractor-carried brass handgun sprayer (Rear's Pak-Tank 100-gallon sprayer, 250 PSI). In 2018, spray application dates with their respective phenological growth stages were as follows: 5 May, pink bud; 17 May, 2.5- to 7.5-cm shoot length; 31 May; 15 June. In 2019, the application dates and growth stages were as follows: 29 April, pink bud; 21 May, 2.5to $7.5-\mathrm{cm}$ shoot length; 31 May; 14 June (Table 1).

Measurement of shoot blight severity, canker incidence, and canker severity. For each inoculated shoot, we calculated shoot blight severity by expressing the necrotic lesion length as a percentage of the total length of the inoculated shoot. The canker incidence, resulting from pathogen invasion of bark on perennial wood from the infected shoots, was calculated as the percentage of cankers that developed on wood after shoot inoculations with respect to the total number of inoculated shoots. Canker severity was measured as the length of cankers that developed on perennial apple wood. In treated, uninoculated control shoots in each spray program, only shoot length was measured (Supplementary Figs. S1 and S2). Shoot blight severity, canker incidence, and canker severity measurements were taken on 18 June, 11 July, and 17 September 2018 and on 19 June, 18 July, and 18 September 2019. The shoot lengths on inoculated untreated control and uninoculated untreated control shoots in spray programs were first measured on 21 May 2018 and 24 May 2019 and continued on the same dates as above for disease measurements. Measurements continued after the terminal bud set on shoots in July to capture fire blight canker development on perennial wood, which continues late in the growing season (Aćimović et al. 2014; Johnson and Temple 2016). Additionally, disease control by a given spray program was calculated as the percentage of symptom reduction compared with the inoculated untreated control.

Statistical analysis. Spray program, time, and interaction of spray program and time were considered fixed factors. The response variables analyzed by the repeated measurements on the tree as the experimental unit were shoot blight severity (as a percentage), shoot length (in centimeters), fire blight canker incidence (as a percentage), and canker length (in centimeters). Random variables were the error associated with the tree as an experimental unit and the error associated with the time measurements taken on each tree. Data on shoot blight severity and length of cankers were analyzed using the MIXED procedure in SAS Studio (SAS Institute). All pairwise comparisons of spray programs were performed using the PDIFF option of LSMEANS, and means separation was completed by hand-drawing lines connecting the means of similar spray programs and assigning letters according to these lines. Canker incidence data were analyzed in JMP Pro 14 by conducting Wilcoxon nonparametric tests, and all pairwise comparisons were performed using the Wilcoxon each pair function (SAS Institute). Means separation was completed by hand-drawing lines connecting the means of similar spray programs and assigning letters according to these lines. Shoot blight severity data from 2018 were arcsine-transformed to normalize the distribution of residuals, and main effects were analyzed using repeated measures best adjusted to unstructured covariance structure $(P<0.05)$. The shoot blight severity data from 2019 were square root-transformed to normalize the distribution of residuals, and main effects were analyzed using repeated measures best adjusted to unstructured covariance structure $(P<0.05)$. Spray program and time effects on shoot blight severity did not interact in 2018 but did in 2019 (Supplementary Table S1).

The canker length data from 2018 were $\log _{10}$-transformed to normalize the distribution of residuals and equalize their variances, and the main effects of spray program and time were analyzed using repeated measures best adjusted to unstructured covariance structure $(P<0.05)$. Program and time effects on canker length did not interact significantly in 2018. The canker length data from 2019 were arcsine-transformed to normalize the distribution of residuals, and the main effects of spray program and time were analyzed using repeated measures best adjusted to unstructured covariance structure $(P<0.05)$. Program and time effects on canker length interacted significantly in 2019.

The 2018 and 2019 data on percentage incidence of developed cankers were used untransformed, and the spray program effect was analyzed by Wilcoxon nonparametric tests $(P<0.05)$. All spray program comparisons were conducted using the Wilcoxon each pair 
function $(\alpha=0.05)$ for each of the three rating time points separately.

\section{Results}

Reduction of shoot blight severity. Disease severity on shoots in treatment 12 (inoculated untreated control) reached 53 and $49 \%$ in the two experiment years (Figs. 1 and 2). No infected shoots were detected in treatment 13 (uninoculated untreated control; Figs. 1 and 2). The effects of PCA and PCA + ASM treatments were ratedependent (high or low). In 2018, the best control (89.5\%) in comparison with treatment 12 (inoculated untreated control) was achieved with program 3, one PCA high, followed by program 4, two PCA high (78.8\%); program 9, three PCA low + ASM (72\%); and program 8, two PCA low + ASM + surfactant (62.6\%; Fig. 1). Spray program 2, two PCA low + surfactant, also significantly reduced shoot blight severity by $50.8 \%$ (Fig. 1). In 2019, the best control $(74.5 \%)$ in comparison with treatment 12 (inoculated untreated control) was achieved with spray program 4, two PCA high, followed by program 3, one PCA high (69.5\%); and program 7, two PCA low + ASM (59.3\%; Fig. 2). In 2019, program 6, PCA minimum $\mathrm{B}$, achieved $51.8 \%$ control of shoot blight severity, and program 9 (three PCA low + ASM) and program 8 (two PCA low + ASM + surfactant) provided control of 46.8 and $50.2 \%$, respectively, but did not differ from the inoculated untreated control.

Spray program 3, one PCA high, provided the best season-long reduction of shoot blight severity, at $79.5 \%$ on average (Figs. 1 and 2 ). Across the two years, PCA + ASM spray programs were inconsistent in reducing shoot blight severity in comparison with the inoculated untreated control, indicating variable responses of shoots to the lower PCA or PCA + ASM rates and their frequencies of application, as well as to different weather conditions (Supplementary Fig. S3).
However, at least one PCA + ASM spray program in each year provided significant reduction of shoot blight severity (Figs. 1 and 2).

As the only preventive treatment, spray program 1 (one PCA low pink bud) was consistently ineffective in reducing severity over both years. Program 5 (PCA minimum A) and copper spray programs 10 (three Bordeaux Mix 0.8-0.2-100) and 11 (three Badge X2) were ineffective in both years. In both years, most of the PCA spray programs reduced treated uninoculated shoot growth in comparison with shoots in treatment 12 (inoculated untreated control) and treatment 13 (uninoculated untreated control) as well as the applied copper spray programs (programs 10 and 11; Supplementary Figs. S1 and S2).

Reduction/prevention of canker incidence on perennial wood. Canker incidence in treatment 12 (inoculated untreated control) reached $20 \%$ and $34.5 \%$ in the two years (Figs. 3 and 4). No cankers developed in treatment 13 (uninoculated untreated control; Figs. 3 and 4). On 17 September 2018, spray programs 3 (one PCA high), 9 (three PCA low + ASM), and 4 (two PCA high) achieved $100 \%, 83.5 \%$, and $66.5 \%$ control of canker incidence, respectively (Fig. 3). On 18 September 2019, spray program 3 (one PCA high) again achieved $100 \%$ control of canker incidence (Fig. 4). On the same date, program 8 (two PCA low + ASM + surfactant) achieved 90.4\% control, program 4 (two PCA high) achieved $71 \%$ control, and program 9 (three PCA low + ASM) achieved 69\% control of canker incidence (Fig. 4). Program 3 (one PCA high) was the best spray program in both years, preventing canker formation by $100 \%$ on average (Figs. 3 to 6). Consistent prevention or reduction of fire blight canker incidence across both years was achieved by programs 3 (one PCA high), 4 (two PCA high), and 9 (three PCA low + ASM; 66 to $100 \%$ ). The significant canker reduction in 2019 by program 8 (two PCA low + ASM + surfactant) was not seen in 2018.

Preventive spray program 1 (one PCA low pink bud), 5 (PCA minimum A), and 6 (PCA minimum B) and the copper spray
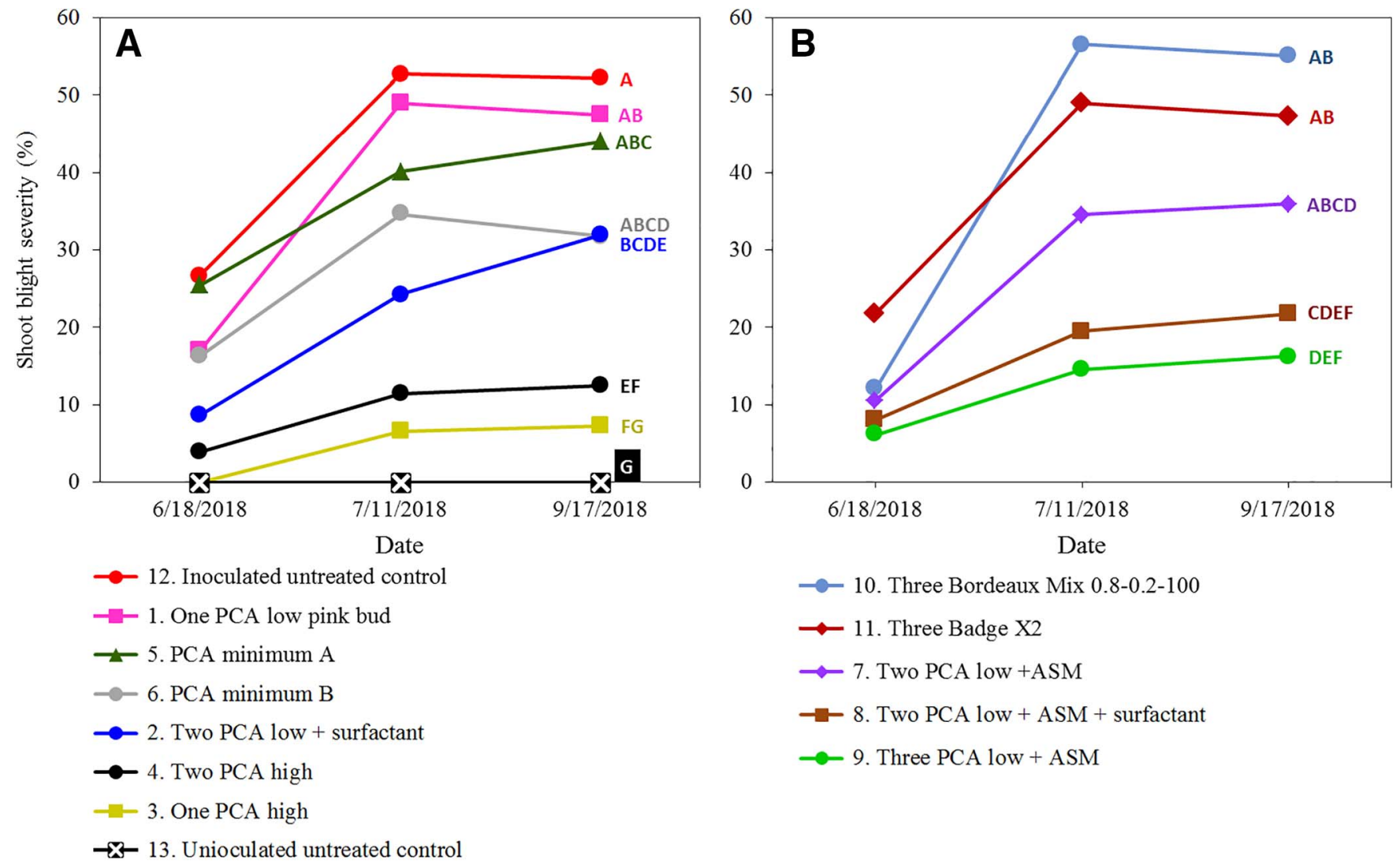

Fig. 1. A, Shoot blight severity on apple cultivar Royal Court after postinfection spray programs of prohexadione-calcium (PCA) in 2018. B, Shoot blight severity on apple cultivar Royal Court after postinfection spray programs of PCA plus acibenzolar-S-methyl (ASM) in 2018. Copper spray program Bordeaux Mix 0.8-0.2-100 consisted of copper sulfate pentahydrate crystals plus hydrated lime, and Badge X2 consisted of copper oxychloride plus copper hydroxide. Application rates are shown in Table 1. Shoots were inoculated on 15 May at 2.5- to 5-cm shoot size $\left(7 \times 10^{8} \mathrm{CFU} / \mathrm{ml}\right)$ and on 14 June 2018 with Erwinia amylovora $\left(3 \times 10^{9} \mathrm{CFU} / \mathrm{ml}\right)$. Spray program lines followed by different letters within and across graphs $\mathbf{A}$ and $\mathbf{B}$ are significantly different $(t$ tests, $P<0.05)$. Each mean consists of three trees, each with a tree mean consisting of 10 shoots per tree. 
programs (10, three Bordeaux Mix 0.8-0.2-100, and 11, three Badge $\mathrm{X} 2$ ) were consistently the least effective in reducing canker incidence in both years (Figs. 4 and 5).

Reduction of canker length on perennial wood. Canker length in treatment program 12 (inoculated untreated control) reached only $0.4 \mathrm{~cm}$ in 2018 , with many spray programs showing greater lengths, and $2.6 \mathrm{~cm}$ in 2019 (Figs. 5 and 6). In 2018, spray programs 3 (one PCA high) and 4 (two PCA high) prevented and reduced canker expansion on perennial apple wood, respectively, but did not statistically differ from the treatment 12 (inoculated untreated control), which had only numerically greater length (Fig. 5). In 2019, spray programs 3 (one PCA high) and 8 (two PCA low + ASM + surfactant) prevented and significantly reduced canker formation on perennial apple wood, respectively, whereas program 4 (two PCA high) did not (Fig. 6). The noticeable numerical differences in canker length between program 3 (one PCA high) and program 12 (inoculated untreated control) in 2018 (Fig. 5) were confirmed by the significant differences in 2019 (Fig. 6). Consistently across both years, numerically, the most ineffective spray programs were 11 (three Badge X2), 5 (PCA minimum A), and 1 (one PCA low pink bud), with canker lengths reaching $1.3,1.2$, and $1.0 \mathrm{~cm}$ in 2018 and $2.6,2.5$, and $2.1 \mathrm{~cm}$ in 2019, respectively (Figs. 5 and 6).

\section{Discussion}

This study demonstrates the importance of early postinfection applications of PCA alone or in combination with the SAR activator ASM. These spray programs reduced shoot blight severity and, more importantly, prevented or reduced the number and size of fire blight cankers on perennial apple wood. Fire blight cankers on the trunk, limbs, and rootstock can kill young and mature trees in high-density apple orchards. During the growing season, we demonstrated that shoot blight lesion expansion, and hence E. amylovora invasion through shoots, was successfully abated by a single postinfection application of PCA of 247 $\mathrm{mg} /$ liter, thus preventing invasion of wood. Therefore, effective postinfection PCA treatments have the potential to reduce or prevent destructive initiation of fire blight cankers on perennial wood and could help reduce tree losses in high-density apple orchards and the number of overwintering inoculum sources. To the best of our knowledge, this is the first field study demonstrating significant reduction and prevention of shoot blight and fire blight canker initiation on perennial wood by postinfection applications of PCA and PCA + ASM on artificially inoculated mature trees of a susceptible apple cultivar. Our PCA spray programs were started after the initial infection event early in the season and should be viewed as part of recovery efforts, with an ongoing fire blight infection, and with more possible later in the summer.

Research on development of programs with PGRs and SARs for postinfection management of fire blight is important because it holds promising potential to lessen the devastating effect of unmanaged epidemics of this disease through reduction of tree deaths and the need for substantial pruning to remove cankers (Aćimović and Meredith 2017; Johnson and Temple 2016; Johnson et al. 2016; Philion and Joubert 2021). The present study is the first to demonstrate the capacity of PGR/SAR for this purpose. We emphasize the need for quick-to-apply postinfection spray programs using plant-manipulating chemicals like PCA and ASM as valuable options in apple management practices required to address the evergrowing challenges of modern fruit production. Some of the most important challenges are (i) the increase in planting of fire blightsusceptible apple cultivars and rootstocks; (ii) the increase in apple acreage with juvenile trees in high-density plantings, in which risks for total investment loss to fire blight are high; and (iii) the increasing potential for unusually warm and wet weather in spring associated with climate change in northern United States, which will favor fire blight outbreaks in the future (Ault et al. 2015; Keenan et al. 2014; Menzel et al. 2006; U.S. Global Change Research Program
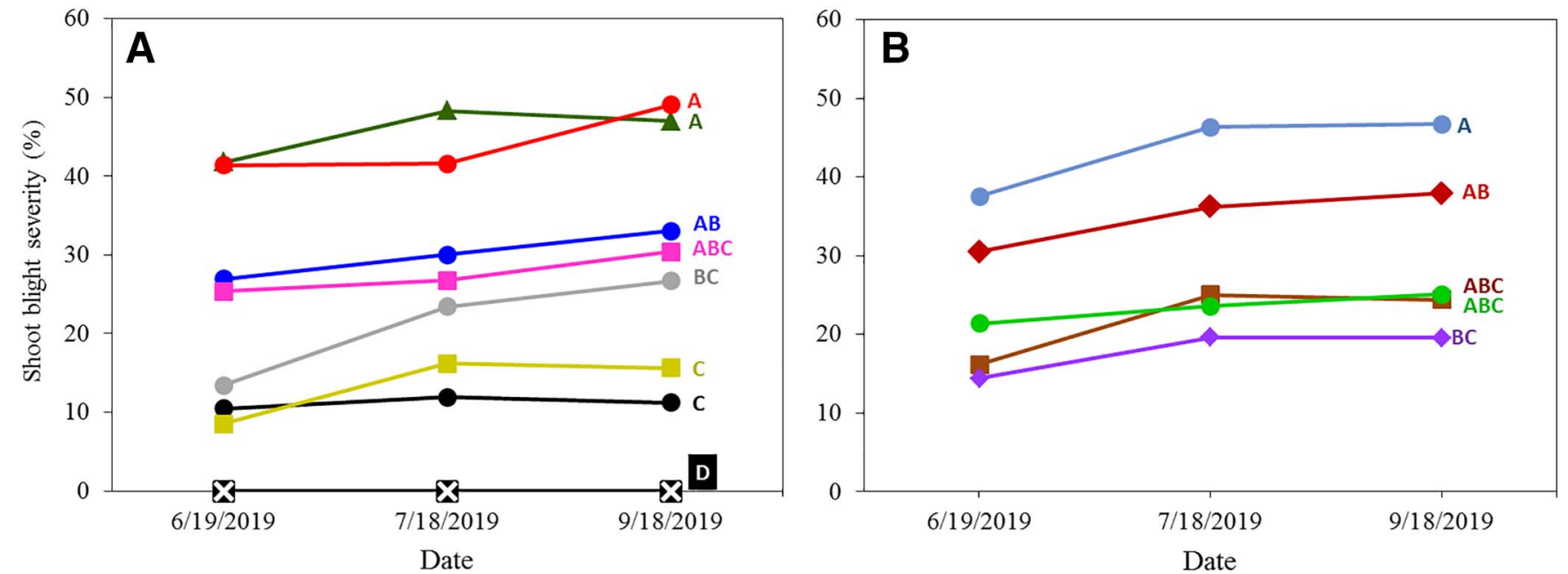

- 5. PCA minimum A
$\rightarrow-12$. Inoculated untreated control
$\rightarrow-2$. Two PCA low + surfactant
-1 . One PCA low pink bud
-6 . PCA minimum B
$\rightarrow-4$. Two PCA high
- 3. One PCA high
$\rightarrow \times-13$. Unioculated untreated control

Fig. 2. A, Shoot blight severity on apple cultivar Royal Court after postinfection spray programs of prohexadione-calcium (PCA) in 2019. B, Shoot blight severity on apple cultivar Royal Court after postinfection spray programs of PCA plus acibenzolar-S-methyl (ASM) in 2019. Copper spray program Bordeaux Mix 0.8-0.2-100 consisted of copper sulfate pentahydrate crystals plus hydrated lime, and Badge X2 consisted of copper oxychloride plus copper hydroxide. Application rates are shown in Table 1. Shoots were inoculated on 18 May at 2.5- to 5-cm shoot size with Erwinia amylovora $\left(2.3 \times 10^{8} \mathrm{CFU} / \mathrm{ml}\right)$. Spray program lines followed by different letters within and across graphs $\mathbf{A}$ and $\mathbf{B}$ are significantly different $(t$ tests, $P<0.05$ ). Each mean consists of three trees, each with a tree mean consisting of 10 shoots per tree. 
2018). With the last challenge in mind, our goal with two inoculations conducted in 2018 was to simulate a year with multiple fire blight infection events, which are reflective of natural conditions in commercial orchards leading to epidemic(s), and thus evaluate our spray programs under high infection pressure from multiple inoculations. We conducted only one inoculation in 2019 to simulate a year with one infection period, which is the most common infection pressure in many years with limited fire blight outbreaks reported in commercial orchards.

We predict that, with the increasing deviation from historically cool and wet spring weather conditions in northern United States (Kunkel et al. 2013; Northeast Regional Climate Center 2019), the significance of postinfection spray programs with PGR and SAR chemicals for fire blight management in apples will increase. As a vegetative growth retardant, PCA causes the thickening of plant cell walls in cortical parenchyma and prevents fire blight pathogen invasion via xylem, reduces the initiation of cankers on perennial wood, and is unlikely to cause E. amylovora resistance development (Spinelli et al. 2005). Postinfection PCA use will reduce the need for reconstructive tree pruning, whereby an already established training system would severely suffer from removal of large limbs or trunk sections with fire blight cankers. The summer or winter pruning for fire blight removal will require less labor and time and will be easier and faster because it would focus only on removal of blossom and shoot blight infections.

Spray applications of PCA or ASM can mitigate an established fire blight outbreak and help reduce the chance for infection renewal in the next growing season. The main concern behind PCA use is growth reduction on 1- to 5-year-old trees, for which filling the row space and reaching the top trellis wire are key priorities in highdensity orchards with dwarf trees. However, application of PCA on young and mature trees to reduce the impact of fire blight, with resulting reduction in tree vigor, is a much more favorable alternative to greater potential tree deaths. In newly planted apple orchards, fire blight cannot be tolerated as a result of increased susceptibility of smaller trees and juvenile host tissues that can impact tree mortality (Johnson et al. 2016). Therefore, a priority to prevent tree death by applying PCA after a fire blight infection event can easily outweigh the perceived penalties in tree growth rate. In the present study, we measured and confirmed the expected PCA effect in different programs on uninoculated shoots (Supplementary Figs. S1 and S2). PCA applied during or several weeks after petal fall has no adverse effects on fruit quality or size, does not cause a carryover effect from one year to another, and does not cause an additive effect from successive annual applications (Miller 2002). We did not observe any changes in yield on apple trees in the present study from 2018 to 2019 and continue to monitor for any potential long-term effects on apple trees after our PCA spray programs. In addition, on mature trees, PCA offers a significant advantage of reducing the chance for new shoot infections and is reducing blight severity on actively infected shoots.

Consistently, in both years, the highest PCA rate applied once or twice after shoot inoculation provided the best control of shoot blight severity. This aligns with the finding that high PCA rates were most important for achieving maximum season-long shoot growth control (Miller 2002). Control of shoot blight severity with preventive PCA

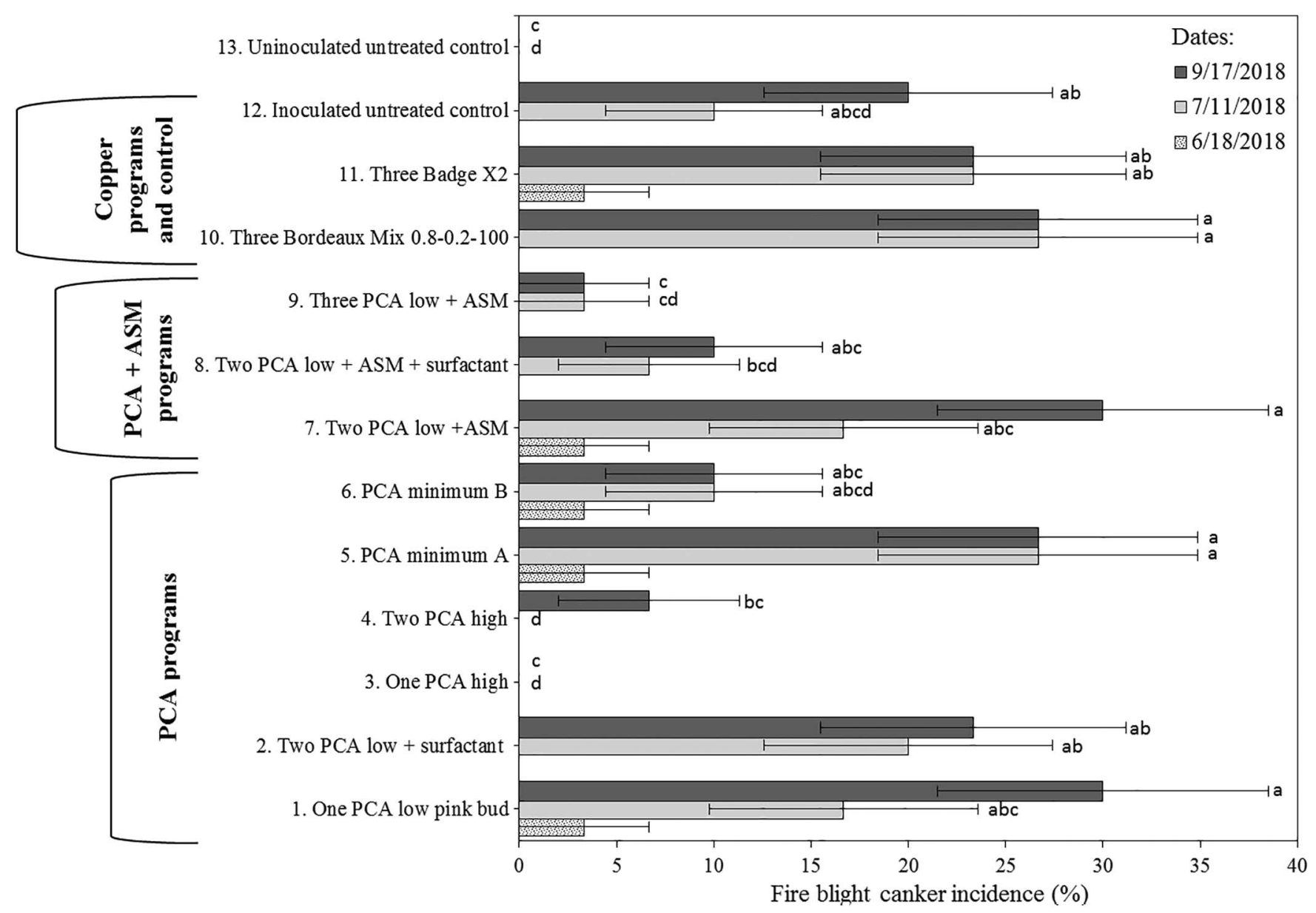

Fig. 3. Development of fire blight cankers on perennial wood of apple cultivar Royal Court resulting from shoot inoculations in postinfection spray programs of prohexadione-calcium (PCA) and acibenzolar-S-methyl (ASM) in 2018. Copper spray program Bordeaux Mix 0.8-0.2-100 consisted of copper sulfate pentahydrate crystals plus hydrated lime, and Badge X2 consisted of copper oxychloride plus copper hydroxide. Application rates are shown in Table 1. Shoots were inoculated with Erwinia amylovora on 15 May at 2.5- to $5-\mathrm{cm}$ shoot size $\left(7 \times 10^{8} \mathrm{CFU} / \mathrm{ml}\right)$ and on 14 June $\left(3 \times 10^{9} \mathrm{CFU} / \mathrm{ml}\right)$. Different letters next to the bars within each date, i.e., bar shade, indicate significant differences between programs (Wilcoxon nonparametric each pair comparisons, $\chi^{2}$ test, $P<0.05$ ). Differences were not significant on 18 June 2018. Each mean consists of 30 shoots. Error bars represent standard error of the mean. 
application(s) is well documented (McGrath et al. 2009; Momol et al. 1998; Norelli and Miller 2004; Yoder 2001; Yoder et al. 1999). In a trial on cultivar Idared, two preventive spray applications of $247.1 \mathrm{mg} /$ liter PCA, applied at 6 to $12 \mathrm{~cm}$ and $15-$ to $20-\mathrm{cm}$ shoot sizes (13 and 20 May), resulted in $85.9 \%$ control of shoot blight severity after inoculation on 2 June (Momol et al. 1998). In inoculated experiments, a preventive application of PCA at $250 \mathrm{mg} / \mathrm{liter}$ followed by $125 \mathrm{mg} /$ liter PCA provided fire blight severity control of 96 to $100 \%$ on cultivar Royal Gala (Norelli and Miller 2004). These preventive applications of PCA, at comparable rates, were equivalent or slightly better than the shoot blight severity control we achieved in postinoculation programs 3 , one PCA high, and 4, two PCA high, on cultivar Royal Court with $247.1 \mathrm{mg} /$ liter PCA applied once or twice (14 days apart).

In the present study, the best prevention or reduction of canker incidence was achieved by one or two applications of $247.1 \mathrm{mg} / \mathrm{liter}$ PCA and then by three applications of $125 \mathrm{mg} / \mathrm{liter}$ PCA $+25 \mathrm{mg} /$ liter ASM. The canker length data support the best control achieved by a single application of $247.1 \mathrm{mg} /$ liter PCA. The fact that two applications of $247.1 \mathrm{mg} /$ liter PCA, but not the single application, led to some canker formation indicates a possible imbalance in plant defense responses or distribution of pathogen-sought nutrients caused by the high cumulative dose of $494.2 \mathrm{mg} /$ liter PCA in this spray program. Previous work showed that, when PCA was applied preventively at $375 \mathrm{mg} /$ liter in a mix with surfactant Regulaid at $0.125 \%$, all inoculated shoots developed tip blight but significantly fewer of them led to lesion expansion into the perennial wood to initiate a canker (Yoder et al. 1999). These results directly support control of canker incidence achieved by our spray program 9, three PCA low + ASM (cumulative dose of $370.8 \mathrm{mg} /$ liter PCA $+75 \mathrm{mg} /$ liter ASM). In the work of Yoder and Marini (2002) with multiple experiments under natural fire blight infections, it was found in autumn that two preventive applications of $125 \mathrm{mg} /$ liter PCA $+250 \mathrm{ml} / 100$ liters of water conditioner Choice $+150 \mathrm{ml} / 100$ liters of LI 700 penetrant/ acidifier on 1 May and 29 June (cumulative dose of $247.2 \mathrm{mg} / \mathrm{liter}$ PCA) significantly reduced incidence of cankers on perennial wood of scaffold limbs or trunks that were initiated from blighted shoots. Canker incidence in this work was reduced by $70 \%$ on apple cultivar Northwestern Greening and by 61 and $96 \%$ on cultivar York Imperial. These results from preventive applications of PCA under natural fire blight infections agree with our control of canker incidence on cultivar Royal Court after a single application of $247.1 \mathrm{mg} / \mathrm{liter}$ PCA. Overall, these results indicate that postinfection application of PCA at a high rate delivered 2 to 3 days after shoot infection can be as effective as two preventive applications of $125 \mathrm{mg} / \mathrm{liter}$ PCA.

In a 2-year study by Johnson and Temple (2016), canker incidence and expansion were quantified on wood of M.26 and M.9-377 rootstocks under a Cameo scion and on M.26 under Gala scion after one or two preventive applications of ASM as a root drench $(50 \mathrm{mg}$ per pot ASM $+500 \mathrm{ml}$ of water) or trunk paint $(15 \mathrm{~g} / \mathrm{liter} \mathrm{ASM}+2 \%$ Pentra-Bark). The first application was when first blossom blight symptoms appeared on pome fruit in the northern United States (21, 26 May), and the second was applied 4 to 6 weeks after the first (2 July, 23 June). Rootstocks were inoculated with E. amylovora on

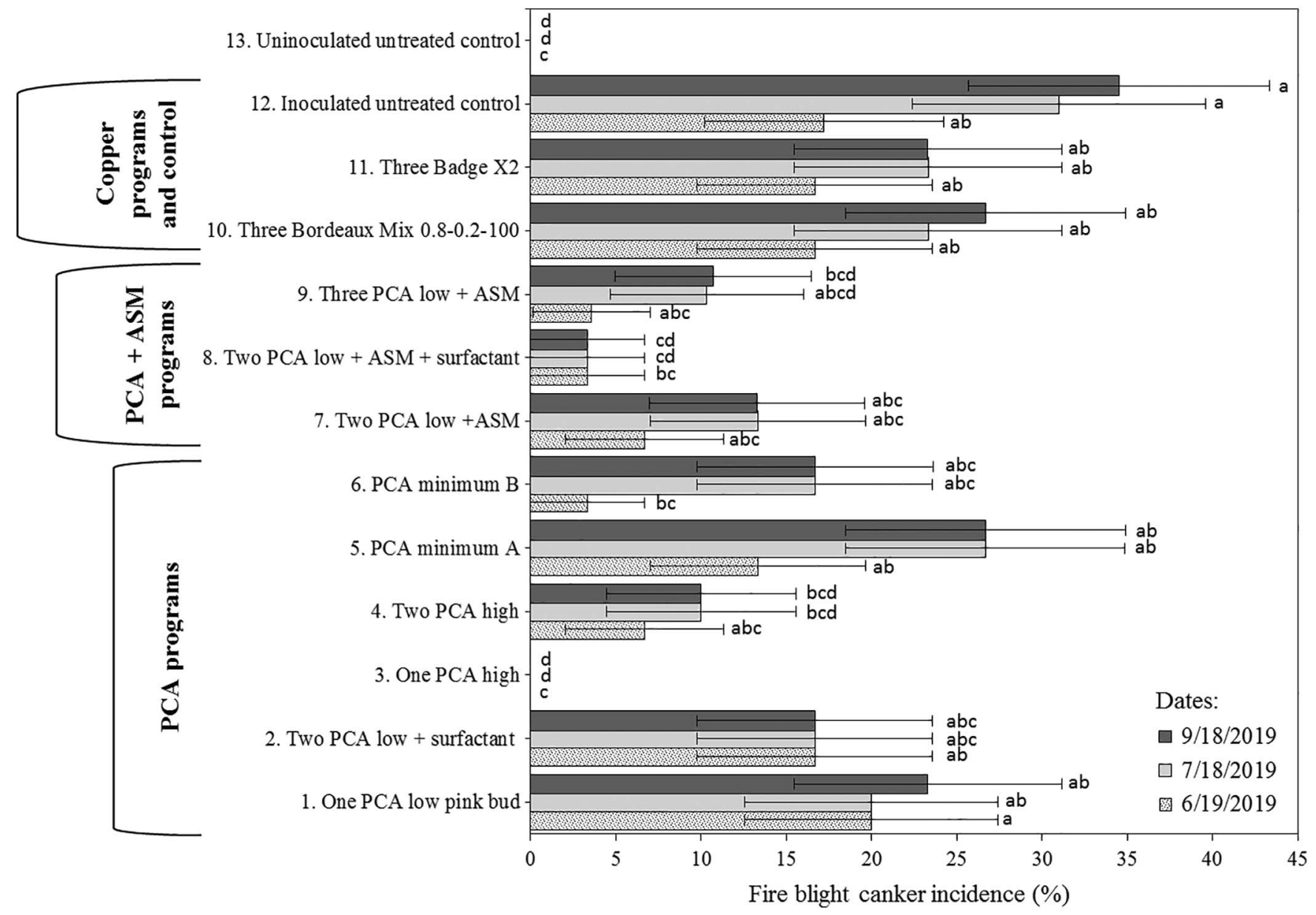

Fig. 4. Development of fire blight cankers on perennial wood of apple cultivar Royal Court resulting from shoot inoculations in postinfection spray programs of prohexadione-calcium (PCA) and acibenzolar-S-methyl (ASM) in 2019. Copper spray program Bordeaux Mix 0.8-0.2-100 consisted of copper sulfate pentahydrate crystals plus hydrated lime, and Badge X2 consisted of copper oxychloride plus copper hydroxide. Application rates are shown in Table 1. Shoots were inoculated with Erwinia amylovora on 18 May at $2.5-$ to $5-\mathrm{cm}$ shoot size $\left(2.3 \times 10^{8} \mathrm{CFU} / \mathrm{ml}\right)$. Different letters next to the bars within each date, i.e., bar shade, indicate significant differences between programs (Wilcoxon nonparametric each pair comparisons, $\chi^{2}$ test, $P<0.05$ ). Each mean consists of 30 shoots. Error bars represent standard error of the mean. 
8 or 6 July. Two to three weeks after inoculation, E. amylovora-inoculated trees treated with ASM showed that $37 \%$ of rootstocks did not initiate cankers on wood, whereas the canker initiations on inoculated controls were $100 \%, 100 \%$, and $75 \%$ on M.26/Gala, M.26/ Cameo, and M.9-377/Cameo, respectively. In the spring of the following season, fire blight canker on wood completely encircled none of the rootstocks treated with two ASM applications, 19\% of rootstocks treated with one ASM application, and 30\% of E. amylovorainoculated control rootstocks. On the rootstocks that received two ASM root drench applications or two ASM trunk paint applications, the canker size was reduced by 78 to $92 \%$. Considering all the differences in ASM applications between this work and our study, we speculate that ASM applied alone, even at a higher rate, would have provided very weak effect on cankers, probably because spraying is an inferior method of application for ASM in comparison with root drench or trunk application. Despite the constraints of our experiment, our results justify the postinfection application of only three spray applications of $125 \mathrm{mg} / \mathrm{liter} \mathrm{PCA}+25 \mathrm{mg} / \mathrm{liter}$ ASM (three PCA low + ASM) for successful reduction of canker initiation. However, because this program had the second highest cumulative dose of $370.8 \mathrm{mg} /$ liter PCA, just behind the two PCA high program (494.2 $\mathrm{mg} /$ liter PCA), the achieved canker reduction could be ascribed mainly to PCA. This may be related to the lack of significant expression of the pathogenesis-related genes (PR)-1a, PR-2, and PR-8 in shoots of 1-year apple trees of cultivar Gala treated with $250 \mathrm{mg} / \mathrm{liter}$ ASM reported by Bonasera et al. (2006), indicating that SAR does not occur in their stems. ASM applications as spray (75 to $150 \mathrm{mg} /$ liter), trunk paint $(15 \mathrm{~g} /$ liter per $60 \mathrm{~cm})$, root drench

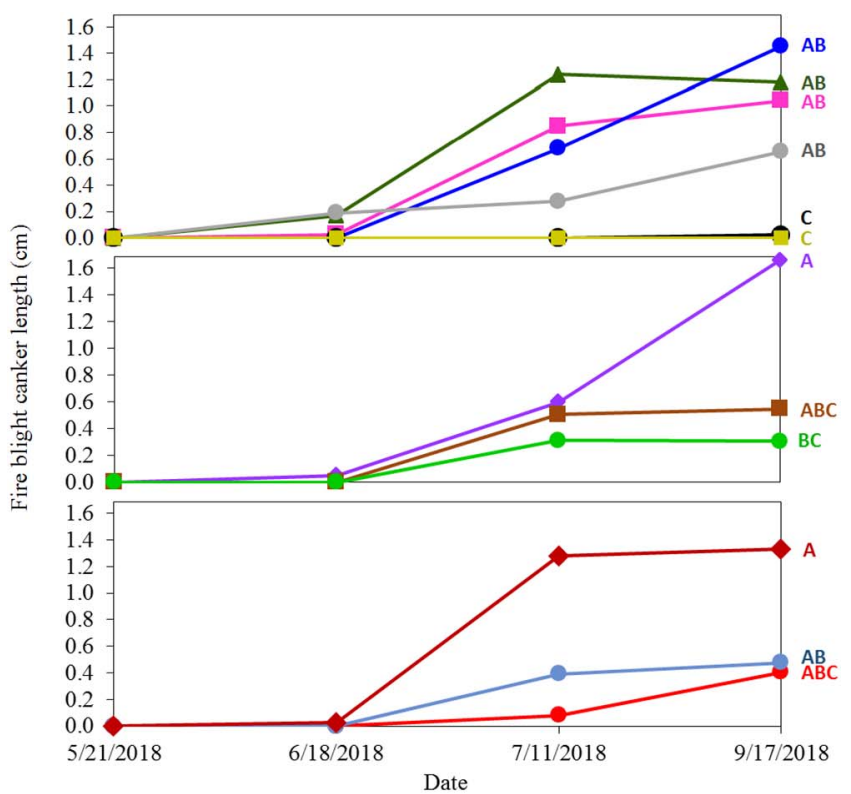

$$
\begin{aligned}
& \rightarrow \text { 5. PCA minimum A } \\
& - \text { 1. One PCA low PK } \\
& - \text { 2. Two PCA low + surfactant } \\
& - \text { 6. PCA minimum B } \\
& - \text { 4. Two PCA high } \\
& - \text { 3. One PCA high } \\
& - \text { 7. Two PCA low +ASM } \\
& - \text { 8. Two PCA low + ASM + surfactant } \\
& - \text { 9. Three PCA low + ASM } \\
& - \text { 12. Inoculated control } \\
& - \text { 10. Three Bordeaux Mix } 0.8-0.2-100
\end{aligned}
$$

Fig. 5. Length of fire blight cankers on perennial wood of apple cultivar Royal Court in postinfection spray programs of prohexadione-calcium (PCA) and acibenzolar-S-methyl (ASM) evaluated in 2018. Copper spray program Bordeaux Mix 0.8-0.2-100 consisted of copper sulfate pentahydrate crystals plus hydrated lime, and Badge X2 consisted of copper oxychloride plus copper hydroxide. Application rates are shown in Table 1. Spray programs, averaged across the three latter dates, followed by different letters are significantly different within and across the three stacked graphs ( $t$ tests, $P<0.05$ ). Each mean consists of three trees, with each tree mean consisting of 10 shoots per tree.
( $25 \mathrm{mg}$ per tree), and trunk injection (170 to $340 \mathrm{mg}$ per tree) cause significant expression of PR-1, 2, and 8 genes in apple leaves, revealing SAR localization to these organs (Aćimović et al. 2015; Johnson and Temple 2016; Maxson and Jones 1999, 2001; MaxsonStein et al. 2002). It remains unclear whether SAR in shoot leaves might have contributed to the PCA's reduction of canker incidence in the present study and should be investigated in the future. Regardless, the effective postinfection programs of PCA in our study demonstrate cessation or slowdown of shoot blight initiation and expansion of fire blight cankers. Further research is necessary to confirm the same results on other susceptible apple cultivars and in different growing regions to capture how local climate and soil fertility factor into the effects of postinfection PCA use.

The lack of efficacy of spray programs such as 1 (one PCA low pink bud), 2 (two PCA low + surfactant), 5 (PCA minimum A), 6 (PCA minimum B), 7 (two PCA low + ASM), and 8 (two PCA low + ASM + surfactant) led to several key inferences. First, the application of PCA at pink bud growth stage, i.e., far before the inoculation, is not effective probably because the shoots as the target are not present at pink bud stage, the rate is too low, or the desired effect weakens over time and with development of new succulent tissues that dilute the PCA dose delivered. Second, the minimum and low rates of PCA applied in these spray programs with more time between applications deliver an insufficient PCA dose into the shoots that is additionally diluted by time and "loses the race" with the higher speed of E. amylovora systemic movement in shoots (Kharadi and Sundin 2020; McGrath et al. 2009). This and the effects of

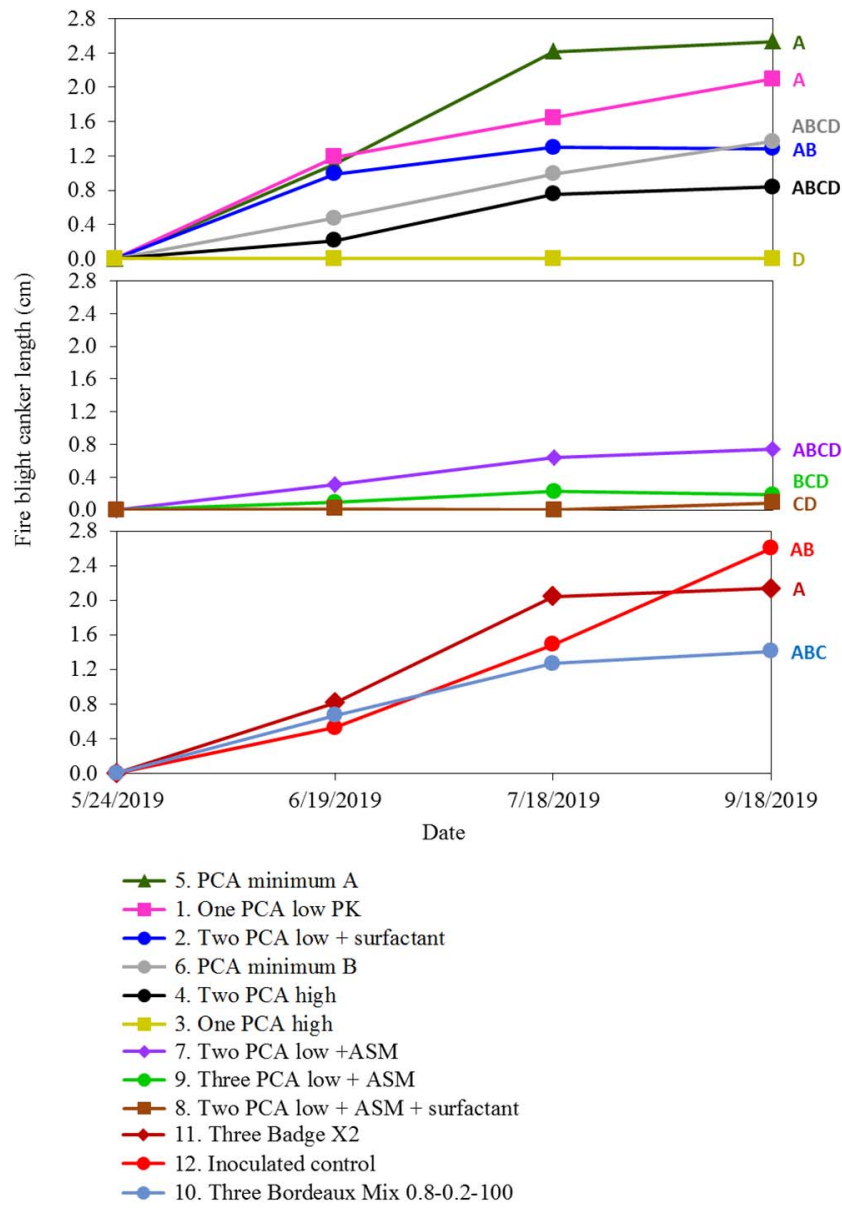

Fig. 6. Length of fire blight cankers on perennial wood of apple cultivar Royal Court in postinfection spray programs of prohexadione-calcium (PCA) and acibenzolar-S-methyl (ASM) evaluated in 2019. Copper spray program Bordeaux Mix 0.8-0.2-100 consisted of copper sulfate pentahydrate crystals plus hydrated lime, and Badge X2 consisted of copper oxychloride plus copper hydroxide. Application rates are shown in Table 1. Spray programs, averaged across the three latter dates, followed by different letters are significantly different within and across the three stacked graphs ( $t$ tests, $P<0.05$ ). Each mean consists of three trees, with each tree mean consisting of 10 shoots per tree. 
programs 3 (one PCA high) and 4 (two PCA high) on shoot blight severity in the present study suggest that the high PCA rates require less than 10 to 14 days to take effect after application, which is contrary to this timeline currently viewed as required for PCA's mode of action to express (Wallis and Cox 2020). This implies that the immediately accessible (i.e., absorbed) dose of PCA that reaches inside the apple shoots plays a key role in achieving the desired host changes (McGrath et al. 2009), triggering quicker interruption of $E$. amylovora invasion through shoots. Hence, the higher the applied PCA rate is, the higher is the dose absorbed in the shoot tissues, and the faster the host changes take place and impact pathogen progress. Finally, the absence of shoot blight and canker reduction by copper spray programs 10 (three Bordeaux Mix 0.8-0.2-100) and 11 (three Badge X2) demonstrates that copper ions, unlike PCA and ASM, did not reach into the shoot tissues to impact E. amylovora.

In conclusion, we proved the concept of postinfection fire blight spray programs with PCA and PCA + ASM. Three spray programs among the 10 we evaluated were successful at preventing or reducing formation of fire blight cankers, with a recommendation of a single postinfection application of $247.1 \mathrm{mg} / \mathrm{liter}$ PCA for use in commercial orchards. These programs are a good approach for situations in which an infection event is reported by fire blight prediction model(s) but a protective antibiotic agent has not been applied in a timely manner. When applied 2 to 3 days after the predicted infection occurs, our proposed PCA-based treatments may help prevent significant tree deaths in mature high-density apple orchards. In years with warmer spring temperatures (Ault et al. 2015; Keenan et al. 2014; Menzel et al. 2006), applications of antibiotic(s) during bloom and postinfection PCA must be timed by using fire blight prediction models to secure maximum efficacy.

\section{Acknowledgments}

The authors thank the faculty and staff of Cornell University's Hudson Valley Research Laboratory, especially Dr. David A. Rosenberger, Crist Bros Orchards Inc., and Cornell Cooperative Extension staff, for valuable advice, help in this work, and experiment plot maintenance. Finally, they thank Dr. Wayne Jurick II for critical review of this paper.

\section{Literature Cited}

Aćimović, S. G., Balaž, J. S., Aćimović, D. Đ., and Reeb, P. D. 2014. High magnitude of fire blight symptom development and canker formation from July onwards on two apple cultivars under severe natural infections. J. Plant Pathol. 96:159-168.

Aćimović, S. G., Martin, D. K., Turcotte, R. M., Meredith, C. L., and Munck, I. A. 2019. Choosing an adequate pesticide delivery system for managing pathogens with difficult biologies: case studies on Diplodia corticola, Venturia inaequalis and Erwinia amylovora. Pages 133-158 in: Plant Diseases - Current Threats and Management Trends, IntechOpen, London, United Kingdom.

Aćimović, S. G., and Meredith, C. L. 2017. Evaluation of dormant copper sprays with bark penetrating surfactants in reduction of Erwinia amylovora in cankers and of low-rate copper sprays in blossom blight control. Fruit Quar. 25:15-20.

Aćimović, S. G., Zeng, Q., Mcghee, G. C., Sundin, G. W., and Wise, J. C. 2015. Control of fire blight (Erwinia amylovora) on apple trees with trunkinjected plant resistance inducers and antibiotics and assessment of induction of pathogenesis-related protein genes. Front. Plant Sci. 6:16.

Ault, T. R., Schwartz, M. D., Zurita-Milla, R., Weltzin, J. F., and Betancourt, J. L. 2015. Trends and natural variability of spring onset in the coterminous United States as evaluated by a new gridded dataset of spring indices. J. Clim. 28:8363-8378

Bertani, G. 1951. Studies on lysogenesis I. The mode of phage liberation by lysogenic Escherichia coli ${ }^{1}$. J. Bacteriol. 62:293-300.

Bonasera, J. M., Kim, J. F., and Beer, S. V. 2006. PR genes of apple: identification and expression in response to elicitors and inoculation with Erwinia amylovora. BMC Plant Biol. 6:23.

Breth, D. I. 2008. Managing fire blight in new apple plantings. N.Y. Fruit Q. 16:9-11.

Brooks, A. N. 1926. Studies of the epidemiology and control of fireblight of apple. University of Wisconsin, Madison, WI.

CBC News. 2014. Fire blight hits $90 \%$ of apple orchards in Nova Scotia. CBC News. https://www.cbc.ca/news/canada/nova-scotia/apple-fire-blight-hits-90of-nova-scotia-orchards-1.2754597

CBC News. 2016. Help on the way for Nova Scotia fruit farmers devastated by fire blight. CBC News. https://www.cbc.ca/news/canada/nova-scotia/fireblight-funding-ns-apple-pear-growers-1.3421282

Crosse, J. E., Goodman, R. N., and Shaffer, W. H. 1972. Leaf damage as a predisposing factor in the infection of apple shoots by Erwinia amylovora. Phytopathology 62:176-182.
Douglas, S. 2006. Fire Blight PP029 (5/03R). The Connecticut Agricultural Experiment Station. https://portal.ct.gov/CAES/Fact-Sheets/Plant-Pathology/ Fire-Blight

Evans, J. R., Evans, R. R., Regusci, C. L., and Rademacher, W. 1999. Mode of action, metabolism, and uptake of BAS $125 \mathrm{~W}$, prohexadione-calcium. HortScience 34:1200-1201.

eXtension (2019) Apple Rootstock Info: G.202. Section: Apples. https://apples. extension.org/apple-rootstock-info-g-202/

Frumhoff, P. C., McCarthy, J. J., Melillo, J. M., Moser, S. C., and Wuebbles, D. J. 2007. Pages 47-61 in: Confronting climate change in the US Northeast. A report of the Northeast climate impacts assessment. Union of Concerned Scientists, Cambridge, MA.

Groisman, P. Y., Knight, R. W., and Zolina, O. G. 2013. Recent trends in regional and global intense precipitation patterns. Clim. Vulnerability. 5:25-55.

Hayhoe, K., Wake, C. P., Huntington, T. G., Luo, L., Schwartz, M. D., Sheffield, J., et al. 2007. Past and future changes in climate and hydrological indicators in the US Northeast. Clim. Dyn. 28:381-407.

Johnson, K., and Temple, T. N. 2016. Comparison of methods of acibenzolar$S$-methyl application for post-infection fire blight suppression in pear and apple. Plant Dis. 100:1125-1131.

Johnson, K. B., Smith, T. J., Temple, T. N., Gutierrez, E., Elkins, R. B., and Castagnoli, S. P. 2016. Integration of acibenzolar-S-methyl with antibiotics for protection of pear and apple from fire blight caused by Erwinia amylovora. Crop Prot. 88:149-154.

Keenan, T. F., Gray, J., Friedl, M. A., Toomey, M., Bohrer, G., Hollinger, D. Y. et al. 2014. Net carbon uptake has increased through warming-induced changes in temperate forest phenology. Nat. Clim. Chang. 4:598-604.

Kharadi, R. R., and Sundin, G. W. 2020. Dissecting the process of xylem colonization through biofilm formation in Erwinia amylovora. J. Plant Pathol. 103:41-49

Koczan, J. M., McGrath, M. J., Zhao, Y., and Sundin, G. W. 2009. Contribution of Erwinia amylovora exopolysaccharides amylovoran and levan to biofilm formation: implications in pathogenicity. Phytopathol. 99:1237-1244.

Kunkel, K., Stevens, L., Stevens, S., Sun, L., Janssen, E., Wuebbles, D., et al. 2013. Regional Climate Trends and Scenarios for the US National Climate Assessment. Part 1. Climate of the Northeast US. NOAA Technical Report NESDIS 142-1. National Oceanic and Atmospheric Administration, National Environmental Satellite, Data, and Information Service, Washington, DC.

Longstroth, M. 2001. The 2000 fire blight epidemic in southwest Michigan apple orchards. Compact Fruit Tree 34:16-19.

Maxson, K., and Jones, A. 1999. Actigard-new fire blight control. The Ohio State University Newsletter Extension, Vol. 3, No. 25.

Maxson, K. L., and Jones, A. L. 2001. Management of fire blight with gibberellin inhibitors and SAR inducers. Acta Hortic. 590:217-223.

Maxson-Stein, K., He, S. Y., Hammerschmidt, R., and Jones, A. L. 2002 Effect of treating apple trees with acibenzolar-S-methyl on fire blight and expression of pathogenesis-related protein genes. Plant Dis. 86:785-790.

McGhee, G. C., and Sundin, G. W. 2011. Evaluation of kasugamycin for fire blight management, effect on nontarget bacteria, and assessment of kasugamycin resistance potential in Erwinia amylovora. Phytopathology 101:192-204.

McGrath, M. J., Koczan, J. M., Kennelly, M. M., and Sundin, G. W. 2009. Evidence that prohexadione-calcium induces structural resistance to fire blight infection. Phytopathology 99:591-596.

Menzel, A., Sparks, T. H., Estrella, N., Koch, E., Aasa, A., Ahas, R., et al. 2006. European phenological response to climate change matches the warming pattern. Glob. Change Biol. 12:1969-1976.

Miller, S. S. 2002. Prohexadione-calcium controls vegetative shoot growth in apple. J. Tree Fruit Prod. 3:11-28

Momol, M. T., Ugine, J. D., Norelli, J. L., and Aldwinckle, H. S. 1998. The effect of prohexadione calcium, SAR inducers and calcium on the control of shoot blight caused by Erwinia amylovora on apple. Acta Hortic. 489:601-606.

Norelli, J. L., Jones, A. L., and Aldwinckle, H. S. 2003. Fire blight management in the twenty-first century: using new technologies that enhance host resistance in apple. Plant Dis. 87:756-765.

Norelli, J. L., and Miller, S. S. 2004. Effect of prohexadione-calcium dose level on shoot growth and fire blight in young apple trees. Plant Dis. 88:1099-1106.

Northeast Regional Climate Center (NRCC). 2019. NRCC State Maps. http:// www.nrcc.cornell.edu/regional/monthly/monthly.html

Pautasso, M., Döring, T. F., Garbelotto, M., Pellis, L., and Jeger, M. J. 2012 Impacts of climate change on plant diseases-opinions and trends. Eur. J. Plant Pathol. 133:295-313.

Philion, V., and Joubert, V. 2021. Use of a growth regulator (prohexadione-Ca) and summer pruning as post symptom rescue treatments following a fire blight infection during bloom. J. Plant Pathol. 103:163-174.

Philion, V., and Trapman, M. 2011. Description and preliminary validation of RIMpro-Erwinia, a new model for fire blight forecast. Acta Hortic. 896:307-317.

Ramirez, H., Alonso, S., and Benavides, A. 2005. Prohexadione-Ca modifies growth and endogenous hormones in the shoot apex in apple trees. Acta Hortic. 727:117-124

Regalis Xtra. 2019. Instructions for use. BASF New Zealand, Auckland, New Zealand.

Santander, R. D., Meredith, C. L., and Aćimović, S. G. 2019. Development of a viability digital PCR protocol for the selective detection and quantification of live Erwinia amylovora cells in cankers. Sci. Rep. 9:11530. 
Schroth, M. N., Thomson, S. V., Hildebrand, D. C., and Moller, W. J. 1974. Epidemiology and control of fire blight. Annu. Rev. Phytopathol. 12:389-412.

Slack, S. M., and Sundin, G. W. 2017. News on ooze, the fire blight spreader. Fruit Q. 25:9-12

Smith, T. J. 2000. Cougar blight fire blight infection risk assessment model. Washington State University. www.ncw.wsu.edu/FB2000f.htm

Smith, T. J., and Pusey, P. L. 2011. CougarBlight 2010, a significant update of the CougarBlight fire blight infection risk model. Acta Hortic. 896: 331-336.

Spinelli, F., et al. 2005. Luteoforol, a flavan 4-ol, is induced in pome fruits by prohexadione-calcium and shows phytoalexin-like properties against Erwinia amylovora and other plant pathogens. Eur. J. Plant Pathol. 112:133-142.

Steiner, P. W. 1988. Maryblyt: a predictive model for eastern apple fire blight. Phytopathology 78:1571.

Steiner, P. W. 1990. Predicting apple blossom infections by Erwinia amylovora using the Maryblyt model. Acta Hortic.: 139-148.

Steiner, P. W., and Lightner, G. W. 1996. Maryblyt TM 4.3. A predictive program for forecasting fire blight disease in apples and pears. University of Maryland, College Park, MD.

Sundin, G. W. 2014. Managing fire blight: new lessons learned from the use of kasumin for blossom blight and apogee for shoot blight control. NY State Fruit Q. 22:9-13.

Sundin, G. W., Castiblanco, L. F., Yuan, X., Zeng, Q., and Yang, C.-H. 2016. Bacterial disease management: challenges, experience, innovation, and future prospects. Mol. Plant Pathol. 17:1506-1518.

Thompson, A., Hilton, R, Achala K. C., Moretti, M., Wiman, N., Pscheidt, J. W., Adams, C., Melathopolous, A. 2021. 2021 Pest Management Guide for Tree Fruits. Oregon State University and Oregon State University Extension Service, Corvallis, OR.

Tullis, E. C. 1929. Studies on the overwintering and modes of infection of the fire blight organism. PhD. thesis. Michigan State College of Agriculture and Applied Science, East Lansing, MI.
Turechek, W. W., and Biggs, A. R. 2015. Maryblyt v. 7.1 for Windows: an improved fire blight forecasting program for apples and pears. Plant Health Prog. 16:16-22.

U.S. Global Change Research Program. 2018. Fourth National Climate Assessment. Chapter 18: Northeast. https://nca2018.globalchange.gov/chapter/18

Van Der Zwet, T., and Keil, H. L. 1979. Fire Blight. A Bacterial Disease of Rosaceous Plants. Handbook 510. United States Department of Agriculture, Washington, DC.

Van der Zwet, T., Orolaza-Halbrendt, N., and Zeller, W. 2012. Fire Blight: History, Biology, and Management. The American Phytopathological Society, St. Paul, MN.

Vanneste, J. L., and Eden-Green, S. 2000. Migration of Erwinia amylovora in host plant tissues. Pages 73-83 in Fire Blight: The Disease and Its Causative Agent Erwinia amylovora. J. L. Vanneste, ed. CABI Publishing, Hamilton, New Zealand.

Wallis, A. E., and Cox, K. D. 2020. Management of fire blight using prebloom application of prohexadione-calcium. Plant Dis. 104:1048-1054.

Winslow, C.-E. A., Broadhurst, J., Buchanan, R. E., Krumwiede, C., Rogers L. A., and Smith, G. H. 1920. The families and genera of the bacteria final report of the Committee of the Society of American Bacteriologists on characterization and classification of bacterial types. J. Bacteriol. 5:191-229.

Yoder, K. S. 2001. Suppression of fire blight of apple shoots by Apogee. Compact Fruit Tree. 34:50-53.

Yoder, K. S., and Marini, R. P. 2002. Demonstration of effectiveness of Apogee for suppression of fire blight on apple shoots in commercial apple orchards. Mt. Grow. 568:16-21.

Yoder, K. S., Miller, S. S., and Byers, R. E. 1999. Suppression of fireblight in apple shoots by prohexadione-calcium following experimental and natural inoculation. HortScience 34:1202-1204.

Zeng, Q., Miller, K., and Cui, Z. 2020. Characterization of the epiphytic growth and host entry points of the fire blight pathogen Erwinia amylovora on apple leaves and flowers. Presented at the 82nd Annual New England, New York, and Canadian Fruit Pest Management Workshop, October 19, 2020. 